\title{
Heavy Metal Pollution in the Receiving Environment of the University of Dar Es Salaam Waste Stabilization Ponds
}

\author{
Adrehem J. Nziku \\ Ministry of Natural Resources and Tourism \\ P. O. Box 9372. Dar Es Salaam. Tanzania \\ Tel: 255-754-695-766Ｅ-mail: adrehermnziku@yahoo.com \\ Dr. Lucy Namkinga (Corresponding author) \\ Department of Molecular Biology and Biotechnology \\ University of Dar Es Salaam \\ P. O. Box 35179. Dar Es Salaam. Tanzania \\ Tel: 255-784-772-552Ｅ-mail: odulajalucy@yahoo.com
}

Received: October 27, 2012 Accepted: November 10, 2012

doi:10.5296/jbls.v4i1.3084 URL: http://dx.doi.org/10.5296/jbls.v4i1.3084

\begin{abstract}
The aim of this study was to examine the availability, concentration levels and bioaccumulation of heavy metals namely; Mercury ( $\mathrm{Hg})$, Cadmium (Cd), Lead (Pb), Zinc ( $\mathrm{Zn})$ and Molybdenum (Mo) in the waste Stabilization Ponds of the University of Dar es Salaam. A total of 135 samples were analyzed, out of which 27 were samples of water, 27 of sediments and 81 samples of fish tissues. Two types of fishes were used namely; Oreochromis niloticus and Clarias gariepinus.

Heavy metal concentration varied significantly between water, sediment, fish species and tissues. $\mathrm{Hg}, \mathrm{Cd}, \mathrm{Zn}$ and Mo concentrations in water and sediment were within WHO safe limits. However, $\mathrm{Pb}$ in water and $\mathrm{Cd}, \mathrm{Pb}$ and $\mathrm{Zn}$ concentrations in sediments were found to be above WHO standards $(\mathrm{p}<0.05)$. Concentration levels for $\mathrm{Cd}, \mathrm{Pb}$ and $\mathrm{Zn}$ were above acceptable levels in Oreochromis niloticus while $\mathrm{Hg}$ was found to be within safe limits in both fish species $(\mathrm{p}<0.05)$. Molybdenum was found to be below the detection limits in Oreochromis niloticus. While $\mathrm{Cd}$ was not detected, $\mathrm{Pb}, \mathrm{Zn}$ and Mo were found highly accumulated in Clarias gariepinus $(\mathrm{p}<0.05)$. Oreochromis niloticus accumulated metals in the increasing order from
\end{abstract}


dorsal muscles < gills < liver while Clarias gariepinus accumulated metals in the decreasing order from dorsal muscle $<$ gills $<$ liver.

Public awareness on the dangers to which fish consumers from the site are exposed is highly suggested and purposeful mitigation measures of stopping all fishing activities in these sites is needed, also animal feeding around the ponds should be forbidden.

Keywords: Heavy metal, Pollution, Stabilization pond, Bioaccumulation.

\section{Introduction}

The contamination of aquatic environments is a public heath problem over the few last decades, pollutants include organic matters, heavy metals, and other inorganic matters (Dirilgen, 2001 in Vinodhin \& Narayanan, 2007). The increasing urbanization, industrialization, mining, agricultural and research activities have resulted in increased quantities of domestic and industrial effluents into the receiving water bodies causing heavy metal pollution and other pollutants. Intermittent storm runoffs from municipal and agricultural farms as well as transport activities significantly contribute to heavy metal load in aquatic environments (Zhang JinTun, 2000, Sheela et al., 2012).

Heavy metals are defined as metallic elements that have a relatively high density (more than $4 \mathrm{~g} / \mathrm{cm}^{3}$ ) and are toxic or poisonous in low concentrations (Karen, 2005), and thus, their presence in the environment is of major public health concern because of their toxicity to many life forms including human beings. Risk to human health associated with consumption of foods contaminated with heavy metals is estimated to be 20 to 40 times higher than the ingestion of contaminated water (Foran, 1990). This is because some aquatic organisms have the capacity to concentrate heavy metals up to $10^{5}$ times the concentration present in water (Guimaraes et al, 1985).

In natural environments, heavy metals occur in a very low concentration, ranging from nanograms to micrograms per liter level (Biney et al., 2008). Additional amounts of such elements enter the environment from natural activities e.g. volcanic activities, continental weathering, forest fire etc. and anthropogenic sources (Karen, 2005). Sediments constitute the most important vehicle of heavy metals and other pollutants in aquatic environments.

Most heavy metals carry positive charges (for example Lead, Zinc and Copper both carry a $2^{+}$ charge). The negative charges in soil particles tend to attract and bind the positive charges on metals cations to form salts or sometimes insoluble complexes, which cannot easily be dissolved in water (www.fairfaxcounty.gov/nvswcd/newsletter/heavymetal.htm).

In acidic situations, the abundance of $\mathrm{H}^{+}$occupy many of the negatively charged surfaces organic matters and clay as a result little room is left to bind metals, hence, more metals remain in the soluble phase becoming easily bio-available (Ibid) depending on the speciation or form of metal in water, soil or air hence more toxic at low pH (Anderson et al, 2000). Furthermore, temperature tends to elevate the solubility and toxicity of dissolved heavy metal salts and also, influence the conductivity of charged particles dissolved in water and their mobility (Tarimo, 
2007).

Several studies have shown that the adverse effects of heavy metals often occur more frequently in aquatic organisms because these elements are ingested by tiny organisms e.g. planktons and levels increase with each step of food chain, a process known as bioaccumulation (Patrick, 2007). Higher concentration levels of heavy metals such as Lead, Cadmium, Mercury, and Zinc have been observed in biological systems such as in aquatic animals or fish, and in aquatic plants or algae (Mamboya, 2000, Lyatuu, 2002, Lyimo, 2002) when compared to the concentration in their surrounding environments.

In many parts of the world fish is used most as a source of nutrition, though fishes are very notorious in their ability to concentrate heavy metals in their muscles.

In developing nations like Tanzania, human chronic exposure to heavy metal pollution is very common but it is difficult to notice because of inadequate knowledge on the symptoms and medical attention. In recognition of the public health effects associated with various heavy metals, WHO, $(1993,1998)$ recommended the acceptable concentration for levels of various heavy metals in drinking water, fish and other food items for human consumption to be 0.001 , 0.003, 0.1, 5 and 0.07 for $\mathrm{Hg}, \mathrm{Cd}, \mathrm{Pb}, \mathrm{Zn}$ and Mo respectively.

The University of Dar Es Salaam, Tanzania, has a number of laboratories and a Health Center all of which use varieties of chemicals for practical training, research works and investigating health problems of patients. Students, staff and other campus dwellers use cosmetics and other chemicals for beauty and/or as medicine. Some of these chemicals used at various points within the campus contain heavy metals whose residues find their destination into the environment directly or through sewage systems.

Fish species like Oreochromis niloticus and Clarias gariepinus found in the receiving environment of the University of Dar es Salaam main campus's waste stabilization ponds are illegally harvested and sold for human consumption within and outside the campus. Grass materials are harvested from various points within the campus for feeding dairy cattle and goats.

This study therefore, investigated the availability and concentration of $\mathrm{Hg}, \mathrm{Cd}, \mathrm{Pb}, \mathrm{Zn}$ and $\mathrm{MO}$ pollutants in water, sediment and bioaccumulation of these metals in different fish species from the receiving environment of the University of Dar Es Salaam main campus waste stabilization ponds.

\section{Methods}

\subsection{Study Site}

This study was conducted in the receiving environment of the University of Dar es Salaam, main campus waste stabilization ponds. The university of Dar es Salaam is situated on the western side of the city of Dar Es Salaam around 6 ${ }^{\circ} 48^{\prime}$ South, 39 ${ }^{\circ} 17^{\prime}$ East $(-6.8000,39.2833)$, on the observation hill, 13 kilometers from the city centre. The main campus occupies 1,625 acres, within Kinondoni district in Dar Es Salaam region, Tanzania. Samples were collected at S $06^{\circ} 47.252^{\prime}$ and $039^{\circ} 12.442^{\prime} \mathrm{E}$; S $06^{\circ} 47.152^{\prime}$ and $039^{\circ} 12.352^{\prime} \mathrm{E}$; and $\mathrm{S} \mathrm{06}{ }^{\circ} 47.035^{\prime}$ and 
$039^{0} 12.388^{\prime} \mathrm{E}$ along the river channel away from stabilization ponds. Fish (Oreochromis niloticus and Clarias gariepinus) samples were caught within this stretch of the stream. All samples were analyzed for heavy metals contamination at Southern \& Eastern African Mineral center (SEAMIC), Dar Es Salaam.

\subsection{Sampling and Analysis of Samples}

A total of 135 samples were collected: 27 samples of water, 27 samples of sediments, 81 samples of fish tissues i.e. liver, gills and dorsal muscles among which, 54 samples were for $O$. Niloticus and 27 for C. garipienus. Stratified random sampling technique was used to mark the sampling area and hence sampling points. The sample categories at each round were labeled as "A1 to A27" for water samples, "B1 to B27 for sediment samples and "C1 to C54 and D1 to D27" for Oreochromis niloticus and Clarias garipienus respectively. At points of sediment sample collections, water samples were also collected using a liter of sterile clean sterile bottles rinsed with nitric acid prior to utilization in order to reduce or remove heavy metal residues. The bottle was lowered into water deep enough to allow it to be filled up with water and then caped properly and transported to the SEAMIC laboratory for analysis. Sediment samples were collected using sediment sampler rinsed with nitric acid prior to usage and kept in a 0.25 liter clean self sealing wide mouthed plastic containers and transported to SEAMIC laboratory for analysis.

The fresh fish samples were captured from the site and kept in clean white polyethylene bags previously washed with detergent, rinsed with de-ionized water and nitric acid in order to reduce or remove heavy metal residues, and then stored in cool containers and transported to Zoology laboratory of the University of Dar Es Salaam for surgical removal of gills, liver and dorsal muscles before they were analyzed for heavy metals at Southern \& Eastern African Mineral center (SEAMIC).

\subsubsection{Digestion of Samples for Analysis}

\subsubsection{Water Samples}

Water samples in the bottles were shaken sufficiently for thorough mixing, and then $50 \mathrm{mls}$ aliquots were filtered on Watman No. 41 filter papers and quantitatively transferred into 50mls volumetric flask before aspiring directly into the Inductively Coupled Plasms for analysis of heavy metals according to Varian (1986).

\subsubsection{Sediment Samples}

A sample of $0.5 \mathrm{~g}$ of sun dried sediments were weighed into a graduated test tube, and then added with concentrated acids $1.5 \mathrm{ml} \mathrm{HCL}$ and $0.5 \mathrm{ml} \mathrm{HNO}_{3}$ digest on a hot plate reaching a temperature of $95^{\circ} \mathrm{C}$. The contents were then left to cool at room temperature, and then diluted with de-ionized water to $10 \mathrm{mls}$ mark. The supernatant solution was then used for heavy metal analysis after 8hours according to Varian (1986).

\subsubsection{Fish Tissues}

A sample of $0.5 \mathrm{~g}$ of fish tissues were weighed into culture tubes then added with $1 \mathrm{ml}$ conc. 
$\mathrm{HNO}_{3}$ and digested in water bath set at $80^{\circ} \mathrm{C}$. After sufficient cooling, samples were digested to 20mls and then analyzed by Inductively Coupled Plasma Atomic Emission Spectroscopy (ICP-AES), using a Varian Liberty-100 Sequential Spectrometer as described by Varian, (1986).

Metals like; manganese $(\mathrm{Mn})$, chromium $(\mathrm{Cr})$, zinc $(\mathrm{Zn})$, copper $(\mathrm{Cu})$, lead $(\mathrm{Pb})$, nickel $(\mathrm{Ni})$, cobalt $(\mathrm{Co})$ and cadmium $(\mathrm{Cd})$ were quantified directly. A multi-element instrument calibration standard was prepared at a concentration of $10 \mathrm{mg} / \mathrm{l}$ (matrix matched to the samples). The calibration was validated using a quality control standard, prepared from stock solutions of each reagent, at $8 \mathrm{mg} / \mathrm{l}$. Samples exceeding the calibration range were diluted appropriately, in duplicate, and re-analyzed. Mercury $(\mathrm{Hg})$ was determined using Cold Vapor Generation ICP-AES. Hg (2+) was reduced to $\mathrm{Hg}(0)$ i.e. a vapor, following reduction of the samples with sodium borohydride $(0.6 \% \mathrm{w} / \mathrm{v})$, sodium hydroxide $(0.5 \% \mathrm{w} / \mathrm{v})$ and hydrochloric acid (10 molar). The vapor was carried in a stream of argon into the spectrometer. Two calibration standards were prepared, at $10 \mu \mathrm{g} / \mathrm{l}$ and $100 \mu \mathrm{g} / \mathrm{l}$ (matrix matched to the samples). Samples exceeding this range were again diluted and re-analyzed. The quality control standards were again prepared from different reagent stock at $80 \%$ of the calibration range (i.e.80 $\mu \mathrm{g} / \mathrm{l}$ ).

\section{Results}

\subsection{Status of $\mathrm{Hg}, \mathrm{Cd}, \mathrm{Pb}, \mathrm{Zn}$ and Mo in Water}

The concentration of $\mathrm{Hg}, \mathrm{Cd}, \mathrm{Zn}$ and $\mathrm{Mo}$ in water were significantly lower than WHO recommended standards, $x_{0.05}^{2}(8)=7.344 ; \hat{\lambda}=0.001453$ for $\mathrm{Hg}, \chi_{0.05}^{2}(8)=7.344 ; \chi^{2}=$ 0.051923 for $\mathrm{Cd}, \chi_{0.05}^{2}(8)=7.344 ; \chi^{2}=2.7244 \mathrm{E}-05$ for $\mathrm{Zn}$, and $\chi_{0.05}^{2}(8)=7.344 ; \chi^{2}=$ 0.01857 for Mo. But the concentration of lead was somehow higher than that recommended by WHO standards, $\chi_{0.05}^{2}(8)=7.344 ; \chi^{2}=5.273 \mathrm{E} 2$.

\subsection{Status of $\mathrm{Hg}, \mathrm{Cd}, \mathrm{Pb}, \mathrm{Zn}$ and Mo in Sediments}

The concentration of $\mathrm{Hg}$ and $\mathrm{Mo}$ in sediments were significantly lower than WHO recommended standards $\chi_{0.05}^{2} \quad(8)=7.344 ; \quad \chi^{2}=0.001709$ and $\chi^{2} 0.05$ (8) =7.344; $\chi^{2}=0.019489$. However, the results indicate that the concentration of $\mathrm{Cd}, \mathrm{Pb}$ and $\mathrm{Zn}$ were appreciably higher than WHO acceptable levels i.e. $\chi_{0.05}^{2}(8)=7.344 ; \quad \chi^{2}=2.33 \mathrm{E} 03, \quad \chi_{0.05}^{2}$ $(8)=7.344 ; \chi^{2}=2.33 \mathrm{E} 3$, and $\mathrm{x}_{0.05}^{2}(8)=16.919 ; \chi^{2}=45.1338$ respectively (Figures $1 \mathrm{a} \& 1 \mathrm{~b}$ ). 
a
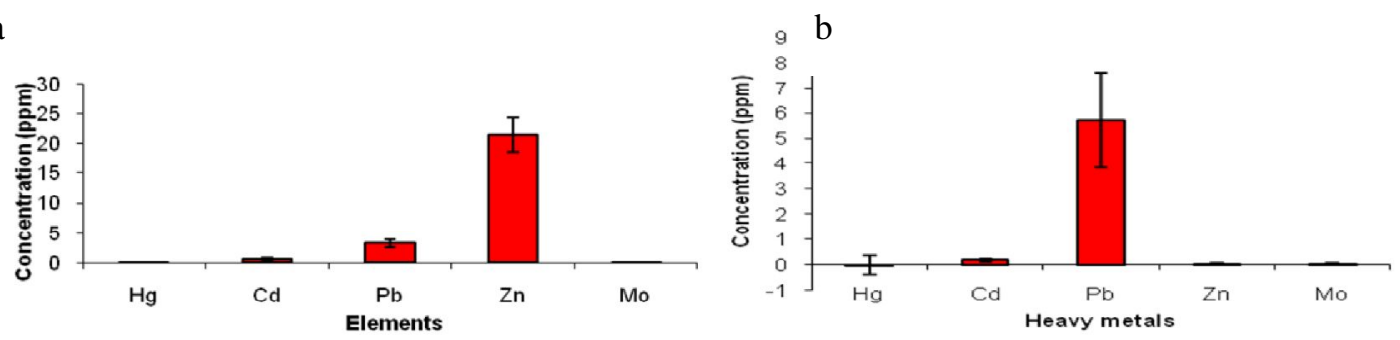

$\mathrm{c}$

d
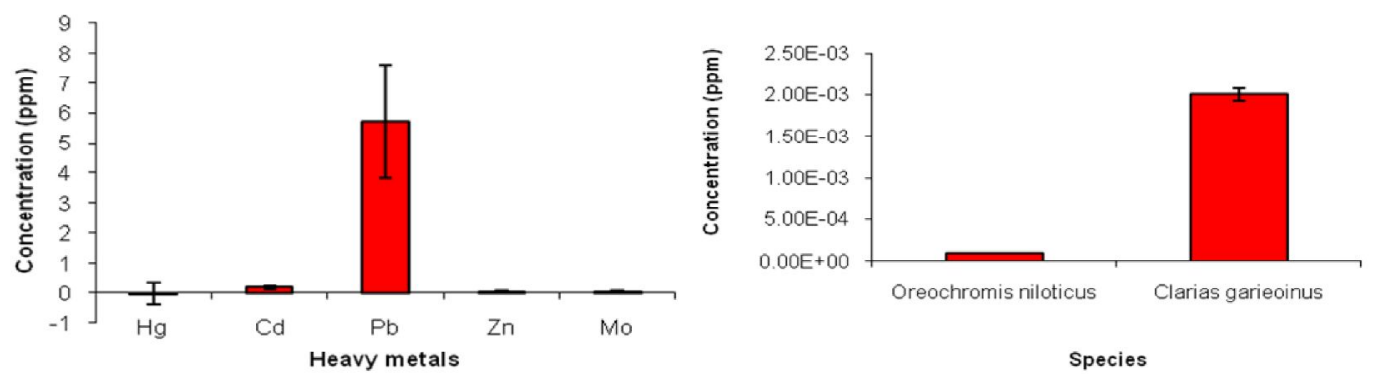

Figure 1. Different Heavy metal concentrations (ppm) in receiving environment of the UDSM - WSP (a) heavy metal concentration in water (b) heavy metal concentration in sediments (c) Concentration of mercury in tissues of different fish species (d) Concentration of Cadmium in tissues of different fish species

\subsection{Trend in Metal Concentration with Increasing Distance from the Ponds}

It was observed that, the concentration levels of the analyzed elements in both water and sediments were decreasing with the increasing distances from the ponds (Figure $2 a \& 2 b$ ).

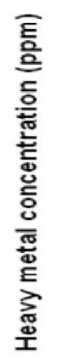

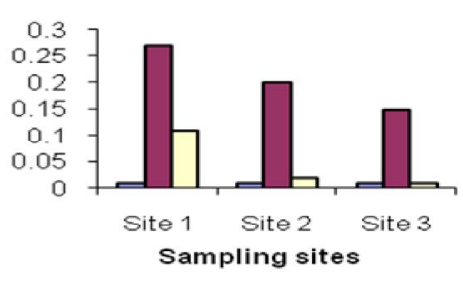

a
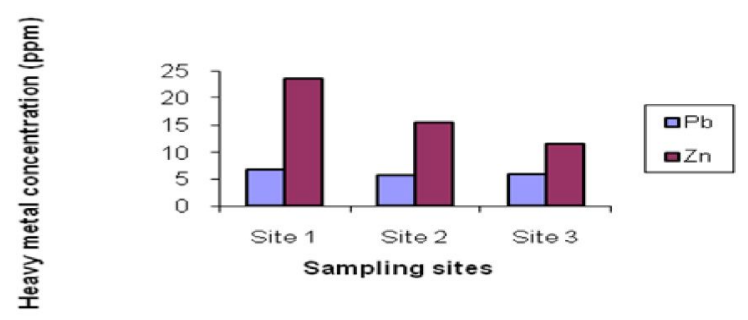

b

Figure 2. Different Heavy metal concentration trend with the increasing distance from the UDSM-WSP (a) Hg, Cd and Mo (b) $\mathrm{Pb}$ and $\mathrm{Zn}$.

\subsection{Concentration Levels of Heavy Metals in Fish Species}

Mercury exhibit appreciably low concentration in both $O$. niloticus and C. gariepinus $\left(\chi_{0.05}^{2}(30)\right.$ 
$=28.336 ; \chi^{2}=2.2^{-09}$ and $\chi_{0.05}^{2}(26)=25.336 ; \chi^{2}=9.6^{-05}$ respectively when compared with WHO standards (Figure 1c).

The concentrations of $\mathrm{Cd}, \mathrm{Pb}$ and $\mathrm{Zn}$ in Oreochromis niloticus was above international recommended standards $\left(\chi_{0.05}^{2}(30)=29.336 ; \quad \chi^{2}=7781.32, \quad \chi_{0.05}^{2}(30)=29.336 ; \quad \chi^{2}\right.$ $=247.901$ and $\chi_{0.05}^{2}(30)=29.336 ; \chi^{2}=1981.501$ respectively. There was no detection of Mo in O. niloticus, however, in C. gariepinus, the concentration level of Mo was found to be higher than recommended standards $\left(\chi_{0.05}^{2}(26)=25.336 ; \chi^{2}=374.5752\right.$.

Cadmium concentration levels in C. gariepinus was below detection limits (Figure 2.a) while that of $\mathrm{Pb}, \mathrm{Zn}$ and Mo were significantly greater than $\mathrm{WHO}$ recommended levels $\chi_{0.05}^{2}(26)$ $=25.336 ; \chi^{2}=55.086$ and $\chi_{0.05}^{2}(26)=25.336 ; \chi^{2}=662.5697$ respectively (Figures 3 a to $3 \mathrm{c}$ ).
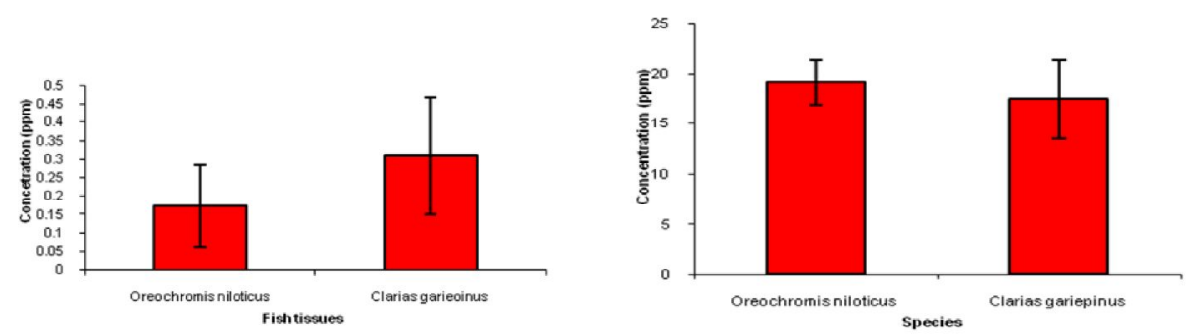

a

b.

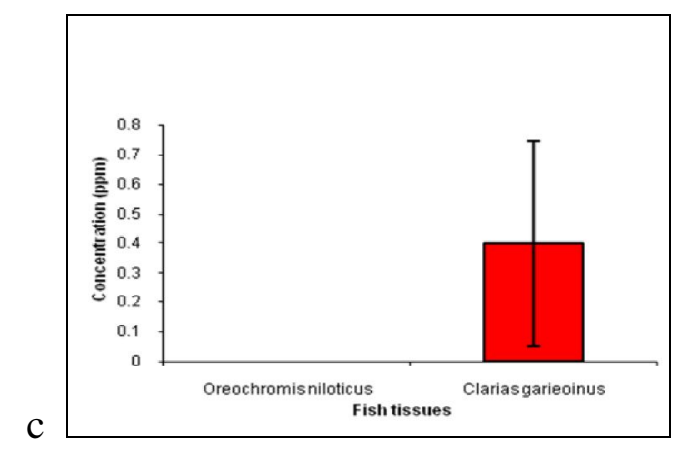

Figure 3.

a. Lead $(\mathrm{Pb})$ concentration in fish found from the receiving environment of the UDSM - WSP

b. Zinc $(\mathrm{Zn})$ concentration in fish found in the receiving environment of the UDSM - WSP

c. Molibden (Mo) concentration in fish from the receiving environment of the UDSM - WSP

$\mathrm{Cd}, \mathrm{Zn}$ and Mo were significantly bio-accumulated in $O$. niloticus (80.62\%), $\mathrm{Zn}$ in both $O$. niloticus and $C$ gariepinus (30.29\% and $23.49 \%$ respectively). While the accumulation of Mo 
in C. gariepinus was 94.49\%, there was no detection of Mo in O. niloticus (Fig 3a to 3c). Mercury and $\mathrm{Pb}$ reflected lower values in both fish species compared to those in their surrounding environment.

The overall comparison of metal content between the two species indicates that $O$. niloticus has accumulated more $\mathrm{Hg}, \mathrm{Cd}$ and $\mathrm{Zn}$ while $C$. gariepinus accumulated more $\mathrm{Pb}$ and $\mathrm{Mo}$. However, the analysis of variance in metal concentration between the two species suggests insignificant difference $\mathrm{t}_{0.05}(4)=0.73, \mathrm{t}=2.132, \mathrm{p}=0.503$.

\subsection{Metal Concentration and Body Size/Weights}

\subsubsection{Oreochromis Niloticus}

The body length of $O$. Niloticus and the concentration of heavy metals indicated a moderately positive correlation $(-1<0.497>0.174)$ for $\mathrm{Hg}$ and negative modest correlations for $\mathrm{Cd}$ $(-1<-0.256<0.506)$, for $\mathrm{Pb}(-1<-0.352<0.353)$ and for $\mathrm{Zn}(-1<-0.0329<0.388)$. No correlation was observed between species size (weight/length) with Mo $(-1<0<1)$. The correlation between metal concentration and body weight in $O$. niloticus was found to be positive moderately associated for $\mathrm{Hg}(-1<0.499>0.171)$ and modest negative association for $\mathrm{Cd}(-1<-0.290<0.449)$, $\mathrm{Pb}(-1<-0.359<0.343)$ and $\mathrm{Zn}(-1<-0.357<0.346)$.

\subsubsection{Clarias Gariepinus}

In $C$. gariepinus the correlation between fish length and heavy metal concentration was weak positive $(-1<0.078<0.842)$ for $\mathrm{Hg}$, moderate negative for $\mathrm{Cd}$, $\mathrm{Pb}$ and $\mathrm{Mo}(-1<-0.467<0.205)$, $(-1<-0.451<0.223)$ and $(-1<0.400>0.286)$ respectively. Modest positive correlation $(-1<-0.256<0.506)$ was observed for $\mathrm{Zn}$. However, metal content and species body weight suggested weak positive correlation for $\mathrm{Hg}(-1<0.131<0.738)$ and a negative moderate correlation for $\mathrm{Cd}(-1<-0.483<0.187)$ and $\mathrm{Pb}(-1<-0.458<0.215)$. A positive modest correlation $(-1<0.369>0.328)$ was observed for Mo while $\mathrm{Zn}$ showed a negative modest correlation $(-1<-0.294<0.443)$.

\subsection{Distribution Pattern of $\mathrm{Hg}, \mathrm{Cd}, \mathrm{Pb}, \mathrm{Zn}$ and Mo in Fish Tissues}

Different concentration values of heavy metals $(\mathrm{Hg}, \mathrm{Cd}, \mathrm{Pb}, \mathrm{Zn}$ and $\mathrm{Mo}$ ) were recorded for in dorsal muscles, liver and gills of the analyzed fish (Figures $4 \& 5$ ).

\subsubsection{Metal Concentration in Tissues of Oreochromis Niloticus and Clarias Gariepinus}

The concentration of $\mathrm{Zn}$ in liver and gills samples from O. niloticus (Figure 5) was significantly greater compared to dorsal muscles from the same species $\left(F_{2}(26)=3.37\right.$; $\mathrm{F}=4.838$. While the concentration of $\mathrm{Cd}$ and $\mathrm{Pb}$ were appreciably lower than the recommended levels, $\mathrm{F}_{2}(26)=3.37 ; \mathrm{F}=1.695$ and $\mathrm{F}_{2},(26)=3.37 ; \mathrm{F}=1.216$ respectively; the concentration of $\mathrm{Hg}$ and Mo were below detection levels (Figure 4). 


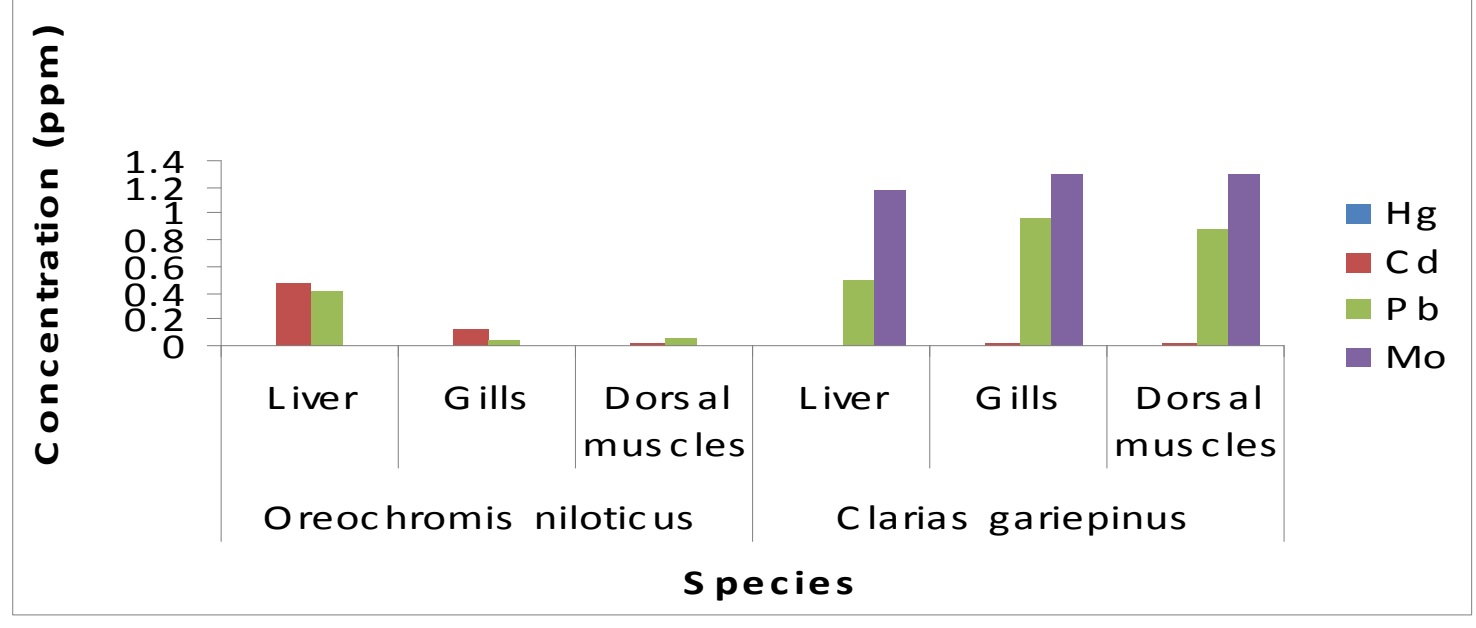

Figure 4. $\mathrm{Hg}, \mathrm{Cd}, \mathrm{Pb}$ and Mo distribution in the tissues of fish found in the receiving environment of UDSM - WSP

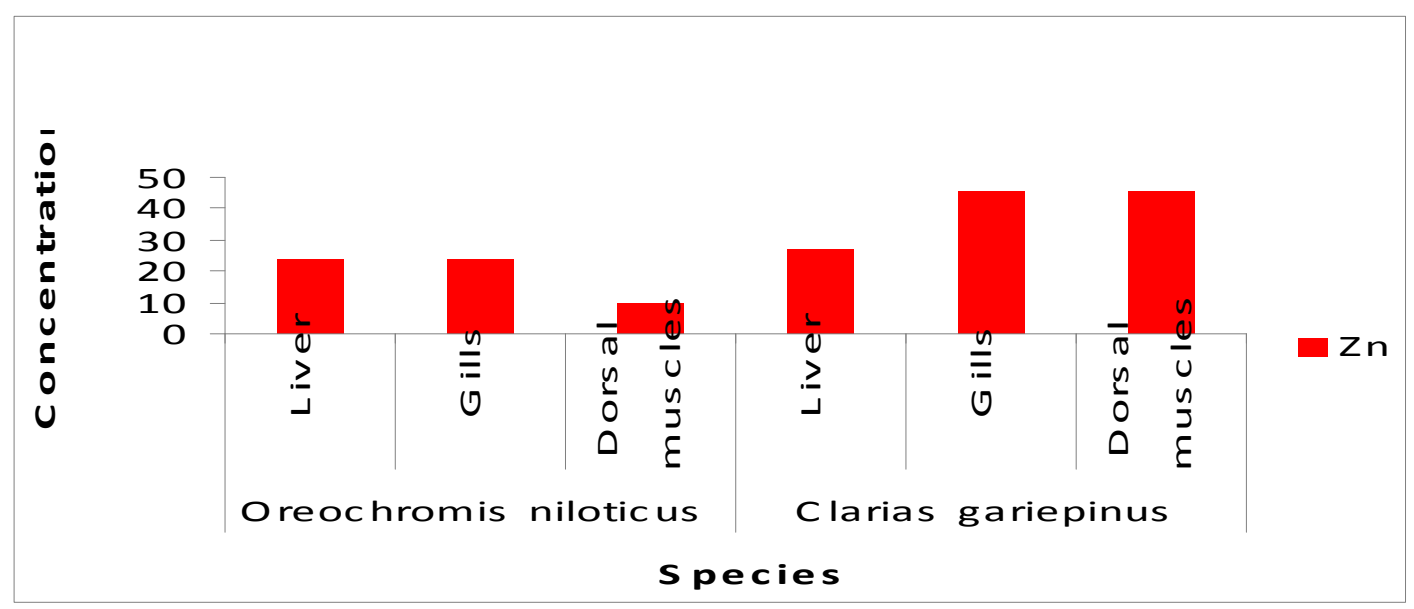

Figure 5. Zinc distribution in tissues of fish found in the receiving environment of the UDSM WSP

\section{Discussion}

\subsection{Status of Heavy Metals Concentration in Water}

The receiving environment of the University of Dar Es Salaam waste stabilization ponds has different concentration levels of $\mathrm{Hg}, \mathrm{Cd}, \mathrm{Pb}, \mathrm{Zn}$ and Mo. Based on the results of this study, $\mathrm{Hg}$, $\mathrm{Cd}, \mathrm{Zn}$ and Mo concentration were found to be within safe limits as per WHO (1993) standards. This might have been due to the effect of sampling time. However, $\mathrm{Pb}$ concentration above WHO (1993) recommended standards suggests anthropogenic enrichment. This might have been caused by $\mathrm{Pb}$ use for various purposes within and outside the University e.g. in laboratories, health center and other residential houses and wastes find their way to WSP. Physical - chemical factors and biological processes occurring permanently in aquatic environments may also influence the availability of different metal elements in water. Because the receiving waters from WSP is used for different purposes like fishing, for livestock, 
irrigating vegetables, and also such water goes to join some rivers or straight to the ocean, there is a greater public health risks.

\subsection{The status of Heavy Metal Concentration in Sediments}

A significant deposition of $\mathrm{Cd}, \mathrm{Pb}$ and $\mathrm{Zn}$ observed in sediments suggests that there is an additional enrichment of the element into the area. $\mathrm{Hg}$ and Mo concentrations values were within the recommended standards suggesting that there is less discharges of the elements in the environment. These concentration values of $\mathrm{Hg}$ and $\mathrm{Mo}$ in sediment and water are in agreement with the findings by Patricia (2008) who finally concluded that Mo in sediment and water is usually found to be lowest in a more oxidizing condition. The fact that $\mathrm{Zn}$ and Mo are essential elements taking part in various metabolic processes and enzymatic reactions they may be naturally be occurring in abundance in the environment in line with the findings of Carlos et al, (2007).

\subsection{Concentration Levels in Fish}

Fish normally tend to concentrate pollutants especially heavy metals from water and/ or from what they consume (Mansour \& Sidky, 2002). The accumulation of heavy metals in fish in this study (Figures $4 \& 5$ ) can therefore, be considered to be an index of such metals pollution in the studied site. The results in this study concur with that of Karadede-Akin \& Unlo, (2007) and Farombi et al. (2007) who noted the presence of higher concentrations of $\mathrm{Cd}, \mathrm{Pb}$ and $\mathrm{Zn}$ in $\mathrm{O}$. niloticus thus suggested that those aquatic systems were exposed to higher concentration levels of those elements through water, food and sediments hence not suitable for human consumption.

\subsubsection{Distribution Pattern of $\mathrm{Hg}, \mathrm{Cd}, \mathrm{Pb}, \mathrm{Zn}$ and Mo in Tissues of Fish}

Heavy metals accumulation in fish tissues appeared to be site specific corresponding with metallic toxicity. The higher concentration of $\mathrm{Zn}$ in the liver and gills reflects the functional roles performed by those tissues/organs. The gills of fish have the thinnest epithelium and are always in direct contact with all the contaminants found in water, as they act like filters, such that, through which metal ions can easily penetrate (Bols et al, 2001).

In $C$. gariepinus, there was no significant difference in concentration of $\mathrm{Cd}, \mathrm{Pb}$ and $\mathrm{Zn}$ in liver, gills and dorsal muscles $F_{2}(26)=3.37,4.22 ; F=1.55$. However, the lower concentration of the element in dorsal muscles indicates low affinity between the element and dorsal muscles possibly because muscles have low protein binding potential (Karadele \& Unlo, 2000). The higher concentration of $\mathrm{Pb}$ in liver may be attributed to the affinity or strong coordination of metallothionein protein with these elements. The differences in metal contents in various tissues of the two species can be explained by considering aspects like concentration level of heavy metals in the environment, ecological needs, metabolism, feeding patterns of the species, exposure time and seasonal variations (Chettodbhay, 2002).

Cd concentration values in $O$. niloticus tissues reflected a decreasing trend from liver, gills and finally in dorsal muscles while in $C$. gariepinus the trend was found to be in the opposite direction. The distribution pattern of Cd observed in liver, gills and dorsal muscles of fish can 
be associated with the fact that the liver, just like in all animals and fish, functions as the organ for detoxication and storage of many types of toxins. These findings are in line with El-Nemr, (2003); Khaled, (2004); Mwashot (2003) who also in their studies found that, Cd concentration values in $O$. niloticus was highly accumulated in kidney and liver. Higher concentration of $\mathrm{Cd}$ in dorsal muscles of $C$. gariepinus may be associated with the life style of the species spending more time at the bottom and or muds. This may easily facilitate easy penetration of toxic metals through skin and gills. Likewise, depending on the nature of the element, the absorbed toxicants can be distributed quickly to other tissues and organs instead of accumulating only in the liver. For example, in this study, the dorsal muscles and gills of C. gariepinus were found to have no significant differences in concentrations of $\mathrm{Cd}, \mathrm{Pb}$ and $\mathrm{Zn}$ in different tissues of fish such as liver, gills and dorsal muscles $\mathrm{F}_{2}(26)=3.37,4.22 ; \mathrm{F}=1.55$. However, the concentration of $\mathrm{Hg}$ in dorsal muscles was significantly higher than in liver and gills $\mathrm{F}_{2}(26)=2.31 ; \mathrm{F}=2.77$ while Mo was found to be higher in gills and dorsal muscles $F_{2}(26)=3.37 ; F=5.428$ (Figures. $3 c \& 4)$. The differences in metal concentration which was observed between species and distribution in different tissues and the amount depend largely on the concentration in the surrounding environment, feeding habit and adaptability of the species to the chemicals and mechanisms developed by the species to excrete the toxicants.

Heavy metal accumulation was found to be high in fish than in their surrounding environment (water and sediments) signifying bioaccumulation effect in upper trophic levels along food chain. These findings are in line with that of Rauf et al, (2009) which again revealed higher heavy metal accumulation in fish than in surrounding environment.

\section{Limitations}

Although this study revealed very interesting results, it yet had some limitations. For instance; the University of Dar Es Salaam, has some new laboratories (molecular labs) emitting a compound "Ethidium bromide" which is highly toxic and carcinogenic. Due to lack of reagents and financial constraints, the compound was not analyzed, and therefore, no one knows its concentration and the magnitude of the problem it may cause in the receiving environment or in the entire aquatic environment where such waste water flows.

\section{Conclusion}

The concentrations of $\mathrm{Hg}$ in fish have been found to be within acceptable limits for both $O$. niloticus and $C$. gariepinus. The concentration of $\mathrm{Cd}, \mathrm{Pb}, \mathrm{Zn}$ and $\mathrm{Mo}$ have been found to be above WHO recommended standards signifying that both $O$. niloticus and $C$. gariepinus from these waters are highly contaminated; hence not suitable for human consumption.

The WSP of the University of Dar es Salaam represents many other areas countrywide with similar status from where people utilize water and biological resources. The problems associated with heavy metal intoxication are many but unfamiliar to many people especially in less developed countries because the knowledge of heavy metal pollution to human health is a relatively new agenda as well as the fact that the health problems are acquired slowly, unnoticed and diagnosis is difficult because their symptoms are always confused with those caused by biological agents. 
It is important that the University improves the performance of waste stabilization ponds so as to reduce heavy metal loads entering the receiving environment. Public awareness campaign geared towards educating people on the health effects that can be acquired through the use of such water for irrigating crops and eating fish and other products from contaminated environments.

\section{Acknowledgement}

The accomplishment of this work could not have been successful without the support and advice of many people. First, the departments of aquatic science and zoology for helping us with sampling equipment and fishing, also identification of fish species. The chemistry department and the Southern \& Eastern African Mineral center (SEAMIC), Dar es Salaam for sample analysis.

\section{References}

Anderson JP, Estabrooks \& McDonald J. (2000). “Duluthi metropolitan area streams snowel and runoff study" Minesota Pollution Control Agency.

Biney C, Amuzu D, Calamari N, Kaba IJ, Mbome H, Naeve PBO. (2008). Review of heavy metals. NC State University, NCSU Water Quality Group.

Bols N, Brubacher J, Ganassin R and Lee L. (2001). Ecotoxicology and inert immunity in fish. Dev. Comp. Immunol, 25(8), 853-873. http://dx.doi.org/10.1016/S0145-305X(01)00040-4

Chettopadhyay BA, Chettorjee A \& Mukhopadhyay SK. (2002). Bioaccumulation of metals in east Calcuta wetland Ecosystem. Aquat. Ecosys. Health manag, 5(2), 191-203. http://dx.doi.org/10.1080/14634980290031848

Carlos E, Ana P, Christina M, Renata M \& Carlos ER. (2007). Heavy metal distribution in two Cetacean species from Rio de Jeneiro State, South -eastern Brazil. Journal of Marine Biology Association of United Kingdom, 2008, 88(6), 1117-1120.

Dirilgen N. (2001). Accumulation of heavy metals in freshwater organisms: Assessment of toxic interaction. Turk.J.Chem, 25(3), 173-179.

El-Nemr AL. (2003). Concentration of certain heavy metals in imported frozen fish in Egypt. $J$. Aqua. Biol. Fish, 7, 139-154.

Farombi E, Adelowo O \& Ajimoko Y. (2007). Biomarkers of oxidative stress and heavy metal levels as indicators of environmental pollution in African Catfish (Clarias gariepinus) from Niigeria Ogun river. Int. J. Environ Res. Public Health, 4(2), 158-165. http://dx.doi.org/10.3390/ijerph2007040011

Fax-fair-county (2005). Heavy metal pollution, www.fairfaxcounty.gov/nvswcd/newsletter/heavy metal.htm- accessed on 29.09.2009.

Foran JA. (1990). Optical spectroscopy. Environ. Sci. Technol, 24, 604-608. http://dx.doi.org/10.1021/es00075a002 
Guimaraes JRD, Larceda LD, Teixeira, VL. (1985). Rev. Brasil. Biol, 42, 553-557.

Javed M and Hayat S. (1995). Effects of waste disposal on the water quality of river Ravi from Lahotre to Head Baloki, Proc.pak.Cong, 2006, 15,41-51.

Karadede H \& Unlu E. (2000). Concentration of some heavy metals in water, sediment and fish species from the Ataturk dam lake (Euphrates). Chemosphere, 41, 1371-1376. http://dx.doi.org/10.1016/S0045-6535(99)00563-9

Karadele-Akin H and Unlu E. (2007). Heavy metal concentration in water, sediments and some benthic organisms from Tigris river. Turkey Environ. Monit Assess, 131, 323-337 http://dx.doi.org/10.1007/s10661-006-9478-0

Karen M. (2005). An assessment of heavy metal contamination in the marine environment/sediments of LasPalas, archipelago Gulf of Panama. School of Life Science, Heriot-Watt University - Edingburg.

Khaled A. (2004). Heavy metal concentration in certain tissues of five commercially important fishes from El-mex Bay, Al-Exandria, Egypt.

Lyatuu HD. (2002). A study of Mercury levels in selected animal tissues at Magusu mining area, Geita in Mwanza - Tanzania. M.Sc ( Env. Science) dissertation, University of Dar Es Salaam.

E. (2002). Evaluation of mercury content in selected food crops grown at Magusu mining area, Geita in Mwanza - Tanzania. M.Sc ( Env. Science) dissertation, University of Dar Es Salaam.

Mamboya FA. (2000). Accumulation and physiological effects of $\mathrm{Cu} \& \mathrm{Zn}$ on the brown macro-algae "Padina boergesenii" and its use as a bio-indicator of heavy metal contamination along the Zanzibar channel. M.Sc. Thesis, University of Dar Es Salaam, Tanzania.

Mwashot, B. M. (2003). Levels of $\mathrm{Cd}$ and $\mathrm{Pb}$ in water, sediment, selected fish species in Mombasa, Kenya - Western Indian Ocean. J Mar Sci. 2(1), 25-34

Rauf A, Javed M \& Ubaidullah M. (2009). Heavy metal levels in three major Carps (Catla catla, Labero rohita and Cirrhina mrigala) from the river Ravi, Pakistan. Pakistan Vet. J, 29(1), 24-26.

Sheela AM, Letha J, Joseph S and Thomas J. (2012). Assessment of heavy metal contamination in coastal lake sediments associated with urbanization: Southern Kerala, India. Lakes \& Reservoirs: Research \& Management, 17(2), 97-112. http://dx.doi.org/10.1111/j.1440-1770.2012.00501.x

Tarimo, I.A. (2007). Heavy metal pollution in water and soils from mining activities in Mererani North, MSc (Env. Science) Dissertation, University of Dar Es salaam.

Vinodhin, R. \& Narayanan, M. (2008). Bioaccumulation of heavy metals in organs of fresh 


\section{Macrothink}

water fish Cyprinus Carpio (Common Carp). Int. J. Environ Sci. Tech. 5(2), 179-182.

WHO (1993). Guidelines for drinking water quality Vol. 2 ( $2^{\text {nd }}$ Ed). Recommendations, WHO, Geneva.

WHO (1998). Addendum to Vol. 2 pg. 281 -283 (Summary tables) Geneva.

Zhang JinTun and Pouyat R. (2000). Effects of urbanization on the concentrations of heavy metals in deciduous forest floor in a case study of New York City. Scientia Silvae Sinicae, $36(4), 42-45$.

\section{Copyright Disclaimer}

Copyright reserved by the author(s).

This article is an open-access article distributed under the terms and conditions of the Creative Commons Attribution license (http://creativecommons.org/licenses/by/3.0/). 